\title{
Culture Matters: The Arts, the Classroom Environment, and a Pedagogy of Entewate Nikonri:Sake : A Study in a First Nations Pre-School
}

\author{
Sheryl Smith-Gilman, McGill University \\ sheryl.smithgilman@mcgill.ca
}

\begin{abstract}
This article brings to light the close relationship between culture, learning and the arts. It recounts the quest of a First Nations (Mohawk) early childhood center in their development of a culturally relevant curriculum whereby culture and Indigenous ways of learning would be seamlessly woven into daily practice. Step by Step Child and Family Center embraced the Reggio Emilia approach. The educators acknowledged how Reggio Emilia's major tenets resonated with Indigenous values as well as seeing congruence in ways of teaching, learning and how relationships are intrinsically interwoven into practice. This research shows how the provocation of the Reggio Emilia approach, and a focus on the arts, provided meaning-making for this community. The study has implications for teacher development, early childhood pedagogy, and may be useful for other Indigenous communities who seek to maintain cultural traditions and identity in educational practices.
\end{abstract}

Keywords: The Arts; Culture and Learning; Early Childhood; Indigenous Thinking

$\mathrm{R}$ ecently I have been exploring the relationship between culture and learning, specifically in Canadian First Nations early childhood education spaces. As an outsider, I was welcomed into the Mohawk community because of shared values in early education that included mindfulness to cultural identity. I was motivated to travel into a journey with a Mohawk early childhood centre and to educate myself about their culture. I consider my researcher identity as having been informed through two-way practice with the teachers and administrators. The experience of the journey felt, at times, like sharing a story of "being and becoming; belonging and longing to belong" (Davis, 2006, p. 201), as I recognized early on that both my and the participants' understanding would evolve, be challenged, transform and grow.

From 2010-2013, I conducted a research project in collaboration with the Mohawk early childhood center (the Step by Step Child and Family Center) in Montreal, Canada. This study detailed an Indigenous community's quest to find innovative ways of reflecting culture in their early childhood programs by placing culture at the forefront of teaching and learning strategies. In the work, we were guided by these key questions: What components might support a paradigm shift to promote quality early education within a culturally relevant context? How could the arts expand children's cultural experiences, and how might culture be woven into daily practice?

Art education was a powerful consideration as the arts have long-provided ways for culture to be preserved and handed down to generations (Wright, 2003). Significant to this study, the arts had the capacity to evoke First Nations values in the child himself/herself and in his/her 
relationships. Mohawk values are deeply embedded in relationships with family and community. Through initial relationships, children come to view themselves, others, and their sense of place in society. Barbara Rogoff (2003), renowned researcher of Indigenous-heritage cultural learning, explains, "All children grow as members of cultural communities so understanding how childhood is supported, constrained and constructed in any community is part of understanding child development" (p. 45). However, recent studies maintain that much work is needed to clarify how culture, in turn, shapes education (Katz, 2010). Rogoff argues that human development must be understood as something that occurs within a cultural process because "culture matters" (p. 28).

Robinson and Jones-Diaz (2006) have suggested that several established early childhood theories and practices reflect outdated ways of thinking about and working with children. They infer that past views do not adequately take into account today's socio-cultural factors, and perpetuate dominant Caucasian and Western thinking and values. Derman-Sparks and OlsenEdwards (2010) have also critiqued early childhood pedagogy beliefs for not examining how notions of "normal" are indiscriminately imposed upon varying cultural groups and exclude and marginalize children who follow different pathways of learning (see also Penn, 2010). Despite the plethora of research in pre-school education, the question remains, how to translate what is known about early schooling into specific communities when their pursuit is to maintain cultural identity.

The research began with the participants' and my common belief in the "provocation" of the Reggio Emilia approach. Inspired and developed over fifty years ago in the northern region of Italy, this early childhood approach has been distinguished worldwide as a model for early childhood education (Kantrowitz \& Wingert, 1991). Initial questions in our study focused on where Reggio Emilia principles might resonate with Mohawk culture, and we found that the creation and development of art studios during the research process greatly impacted investigation. In fact, the art studios provided place and space for children's participation in the arts whereby meaningful experiences unfolded: the integration of thought, skills, emotions and communication, all significant to First Nations ways of teaching and learning. The center's focus on integrating environmental principles into learning was also important as it provoked our understanding of the role of the arts in relation to cultural identity in this First Nations early childhood program.

\section{Why Reggio Emilia?}

The Reggio Emilia philosophy, informed today by theories of Vygotsky, Montessori, Piaget, Bruner and Gardner (and many others), is sustained by guiding principles such as: the image of the child; the role of the teacher, project-based learning around a negotiated curriculum, and a devotion to learning materials and the environment. These principles are tightly intertwined whereby each tenet impacts, and is impacted by the other (Gandini, 1998).

Reggio pedagogy places great value on approaches to teaching, learning, and advocacy for young children. Educators stimulate learning through their vigilant observation of their students; an ongoing process of uncovering what children know, what they are inquisitive about, and what challenges them. The educator's role involves recording meaningful observations which are used in teaching to expand the child's interests, understandings and social abilities. A teacher's documentation might be represented by photographs, written conversations, videos, or displays of children's work (e.g. sketches, paintings, or clay depictions). Documentation also serves as a script whereby teachers can negotiate with children the path of their learning along with providing for teacher self-reflection and collegial planning. This investigative work offers rich experiences to grow from, for both teacher and student. 
One of the fundamental features of the Reggio Emilia approach is the care and aesthetic concentration afforded to every space in the school and classroom. Art studios incorporate a variety of materials, and are organized so that children may work independently or in small groups. The arrangement of studio spaces focuses on the principles of relationships, manipulation of light and exploration of materials, and seek to bring the natural world into the classroom.

The educators at the Step by Step Child and Family Center had been exploring ways to sustain their First Nations culture and were drawn to the Reggio Emilia approach. Research suggests that, of all the early childhood education programs Reggio pedagogy resonates in Indigenous educational contexts (e.g. Fraser, 2006; Hughes, 2007, New, 2007) because it reflects a sensitivity to local culture (New, 2007) and diversity (Fraser, 2007). At Step by Step, the educators recognized that by perceiving the world through the lens of the child, they gained the ability to re-structure, transform and develop teaching and learning experiences; this perspective aligned Mohawk values with Reggio principles. In the Reggio approach, the child is seen as the main protagonist in his/her investigations; the central collaborator and communicator with his/her peers and adults (Rinaldi, 1998). This perspective supports a key tenet of First Nation thinkingthe centrality of the child (Porter, 2008) as demonstrated in this statement: "Children are not our possessions, they are gifts to us. This is the belief of our people" (Joint First Nations/Inuit/Federal Child Care Working Group, 1995, p. 9). Step by Step's teachers were always mindful of the centrality of the child as they sought to maintain learning in "continuity with Indigenous values and beliefs" (Clavir, 2002, p.74). It was difficult, however, for them to know exactly how to integrate culture into daily curriculum without making "culture" a token appendage. Nonetheless, the Step by Step community had followed their quest to unearth a meaningful and connected approach to their culture and they found that grounding in the principles of Reggio Emilia pedagogy.

\section{Developing the Inquiry}

The research occurred over three phases, each presenting its own questions and challenges. During this time I collaborated with 10 classroom teachers, two administrators, the executive director of the school and approximately 130 children ranging in age from 18 months to 5 years. I discuss all three phases briefly here to provide context, however this article focuses mainly on Phase Two of our study. The guiding question for all three phases was: What would support seamless integration of First Nations culture into the Step by Step Child and Family Center's program?

Phase One (March 2010-June 2010) explored critical intersections between Reggio and Mohawk principles that unfolded as we sought to design a cultural curriculum for the center. We also initiated teacher's practices of documentation, collaboration, project-based learning, and the preliminary integration of arts-based approaches. Phase Two (August 2010 - June 2011) extended the objectives of Phase One and was focused on the development of the art studios (referred to by the school as Entewate'nikonri:sake (Mohawk) ${ }^{\mathrm{i}}$. The Center constructed studios for each classroom; a distinctive space and place to encourage children's skills in the language of art, and to apply the Reggio approach of the 'environment as a third teacher.' ii In this phase, my role evolved from being a coach to a teacher mentor and model, as I guided educators and children in their experiences in the studios. I consider this phase to be the most important chapter of the study, as it reflected the ways teachers began to develop abilities guided by Mohawk cultural values and thinking. In Phase Three (August 2011-September 2012) I shifted to the role of consultant, pulling back to support teachers as they took over the studio work. Here, the educators continued to explore 
a variety of arts-integrated approaches as they guided students through the culturally relevant projects that emerged in their classrooms.

\section{Research Methodology}

In designing this qualitative study, I drew on five methodological traditions: participatory action research; grounded theory; narrative inquiry; arts-based forms of inquiry and Indigenous approaches to research. By using multiple perspectives, divergent theoretical outlooks, diverse methods of gathering, and mindful analysis and interpretation of data, the research opened important pathways to learning (Arsenault \& Anderson, 1998). I required a flexible approach, one that would allow me to draw on different methodologies at pivotal times in the research as it evolved in collaboration with participants. None of these methodologies became the dominant paradigm for the study; instead, each became a resource for designing the research. Data collection included interviews, focus group discussions, observations, journal reflections and field notes. Every phase involved arts-based inquiry; however the approach was more prominent during Phase Two and Phase Three.

During periods of analysis I went through processes of memo-ing descriptive findings, creating broad themes, highlighting portions of texts and organizing them by code. This lengthy and challenging procedure reflected both "coarse-grained and fine-grained analysis" (ButlerKisber, 2010). My field notes and journal reflections were valuable tools because they provided a chronological record of experiences, as well as my personal thoughts on who and what was changing. My documentation also corroborated and/or disconfirmed what was emerging in the data. My analysis of data followed procedures of constant comparative methodology (Maykut \& Morehouse, 1994) to uncover broad themes that investigated the initial research question: What role can the studio and arts play in developing cultural identity?

\section{A Pedagogy of Entewate'nikonri:sake}

Phase Two began with the educators' appreciation of how Reggio Emilia principles and Mohawk values (i.e. significance of relationships, connections to the natural world and the centrality of the image of the child) connected. The challenge for educators was "to create a context in which children's curiosity, theories and research [are] legitimated and listened to" (Rinaldi, 2006, p. 121), in order to place culture at the core of practice. This objective was reflected in the pedagogy of Entewate'nikonri:sake.

The emphasis during the second phase was on the teachers' support for the children's investigations of culturally related projects through the arts. Research has identified arts practices as critical for children's learning in all domains (e.g. physical, social, emotional, aesthetic, language, cognitive) (Snyder, 2001). The following questions emerged: What role would the studios play in developing Mohawk culture in early childhood education? How could the environment become "... a place of research where imagination, rigour, experiment, creativity and expression would interweave and complete each other" (Vecchi, 2010, p. 35)? Would the offering of art as a mode in which to express ideas expand the children's cultural experiences? If so, how?

During this phase, the pedagogy of Entewate'nikonri:sake developed. It was the studio; the physical space where thought and artistic expression away from the "busyness" of the classroom, that was most critical. The teachers added to their studio environments: c.d. players, cultural artifacts and generous amounts of art materials. They attended to their materials: categorizing new paint brushes by size; grouping paint by shade and placing jars on low shelves for children to access; arranging small tables diagonally between large windows so the children 
would be provided with light and a clear view of the outdoors. The educators also included symbols of First Nations' culture as part of the décor: a dream catcher; a kastowah (male headdress); natural items such as pine cones and twigs placed in baskets; jars of shells or stones; a sculpture of a turtle or bear (See Fig. 1 \& Fig. 2). Their aesthetic considerations augmented the developing pedagogy of Entewate'nikonri:sake.

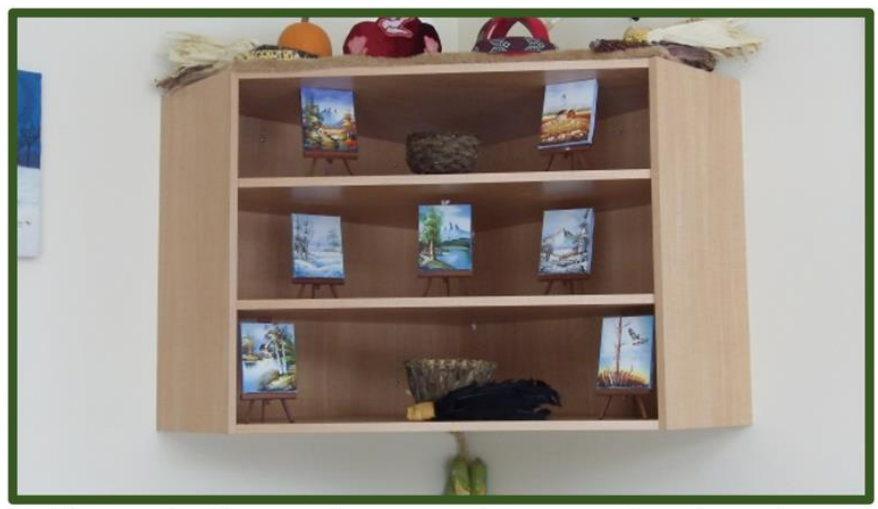

Figure 1. Kastowahs, natural items and native prints

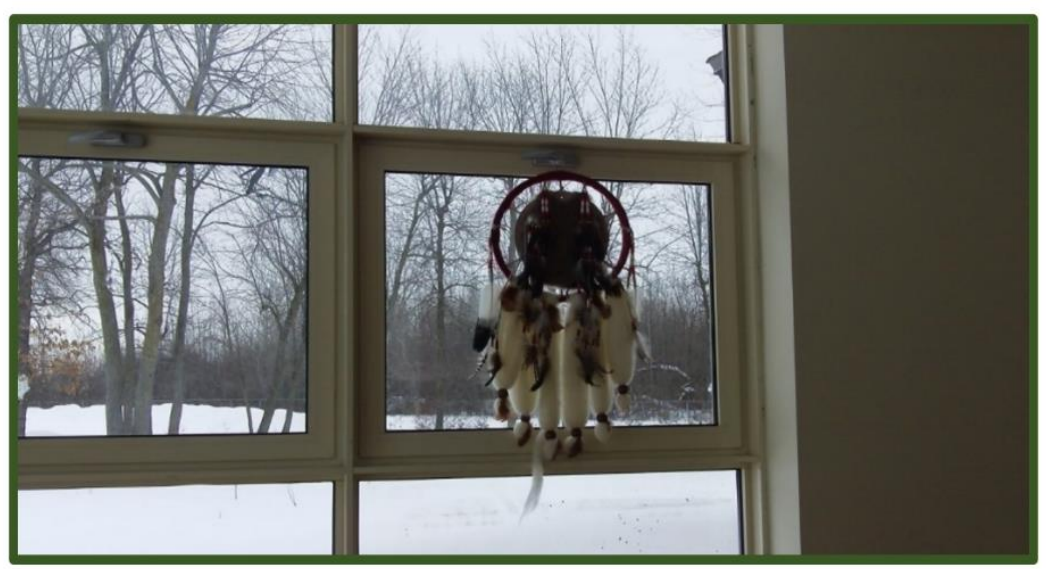

Figure 2. Native dream catcher in the atelier window

\section{Theoretical Framework}

My early discussions with the administrators focused on envisioning children's learning in an inspiring environment that would offer a variety of materials for children to test their theories and develop their cultural understandings. We noted that teachers needed support in their implementation of the pedagogy of Entewate'nikonri:sake: guidance in developing skills and the confidence to facilitate a different kind of learning.

Our research led us to the work of Ann Pelo (2007), an American mentor teacher influenced by the pre-schools and ateliers of Reggio Emilia who also felt uncertain about how to bring theory to praxis. We appreciated Pelo's (2007) strategy to build relationships with art media over phases, and focused on learning to first speak "the language of art" (e.g. line, shape, colour, form, texture): ....and see how it [art medium] feels in our hands, how it moves across the paper; holds its shape. We experiment with tools and with techniques. Through engaged exploration, we can become comfortable with the art medium... We can claim the language of art as our own. (Pelo, 2007, p. 7) 
Our opening encounters with the children in studio, therefore, began with the introduction of visual art media and concepts to develop this language. We appreciated Pelo's (2007) belief in a "culture of inquiry" (p. 50) that would extend practices of inquiry with young children, and created our own 'Cycle of Inquiry' to map out our strategy.

\section{Map: A Cycle of Inquiry}

Vecchi (2010) claims that young children in school are frequently asked to "produce" in "hurried actions" and in "short periods of time" (p. 31), which often provides experiences of very little meaning. We wanted to create opportunities for children to develop skills over extended periods of time, and researched Jeanne Goldhaber's 'Cycle of Inquiry' to support the educators' learning based on an emergent curriculum (Gandini, Hill, Cadwell \& Schwall, 2005). Goldhaber suggested that recorded children's experiences could be identified as “...cycles of hypothesis, experiments and conclusions or cycles of experience, reflection and expression" (Gandini et al., 2005, p. 190). Each undertaking along the process of inquiry would build on the previous step and allow learning to follow a continuum. With this understanding, the administrators and I created our own Cycle of Inquiry before school began. After several discussions of how we envisioned teachers and children's roles during the various stages of work, we created a visual framework. This cycle was specifically intended to connect to arts and project experiences occurring in the studios.

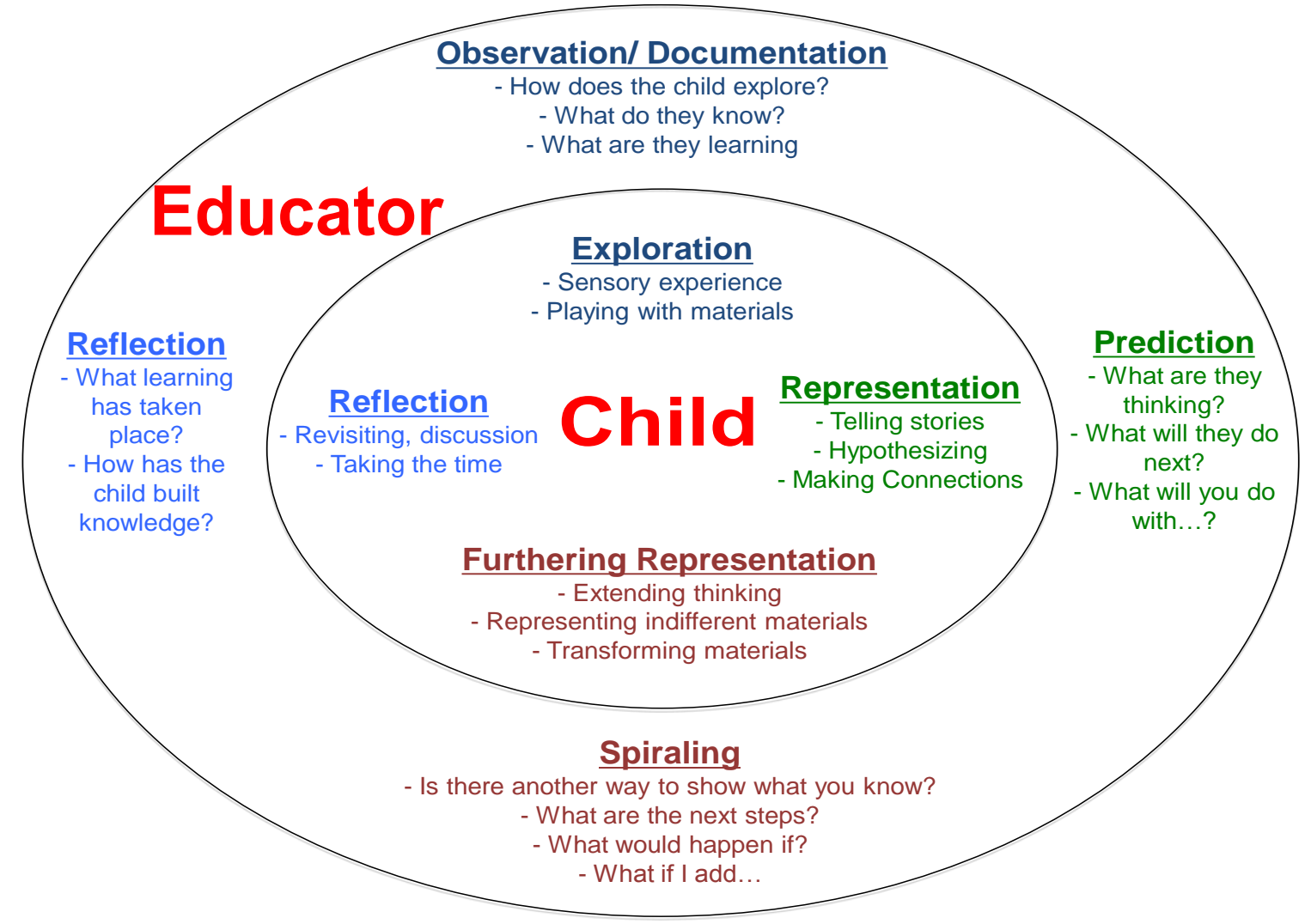

\section{Step by Step's Cycle of Inquiry}

The cycle situated educators alongside the children, asking that they observe and listen carefully to their questions, theories and experiences. Our efforts in designing a 'tailored' Cycle of Inquiry affirmed that a paradigm shift was occurring. My continual dialogue with the two 
administrators kept us on track and illuminated their movement away from a theme-based curricular approach (with add-ons of cultural topics) towards a project approach involving cultural values. Our understandings were grounded in a constructivist theory of how children learn (e.g. Piaget, 1966; Vygotsky, 1978) and affirmed our belief that young children are capable of constructing knowledge for themselves, both individually and socially.

\section{Arts Exploration: Teachers First}

Start-up week at the Center was met with excitement and activity as the final stages of the construction of the studios progressed. During four pedagogical days before the children arrived, teaching teams were introduced to the notion of simply exploring materials. To start, teachers read selected articles that discussed the practice of various art media when working with young children. They were then invited into the gym at their leisure to discover and play with a variety of materials that were set out at individual centers: One center offered clay with sculpting tools and baskets of natural items (pine cones, stones, feathers); another area was organized with jars of black and white paint, mural paper and assorted sizes of paint brushes. A different center was arranged in a dark corner of the gym, where an overhead projector was made available so educators could play with light using items from a basket of materials that contained feathers, stones, twigs, combs, keys and other found resources. At each center educators were asked to document their activities by taking notes and photographing important moments (See Fig. 3). During those four days, the teaching teams engaged with and entered into the pedagogy of Entewate'nikonri:sake.

Debriefing after these experiences provided teachers with time for reflective discussions, and sensitized them to the foundations of the Cycle of Inquiry. Having unhurried time, open-ended sensory explorations, telling stories and working in small groups, representing, reflecting and revisiting experiences were meaningful to the teachers. These experiences provided context for their practice and encouraged future reflections.

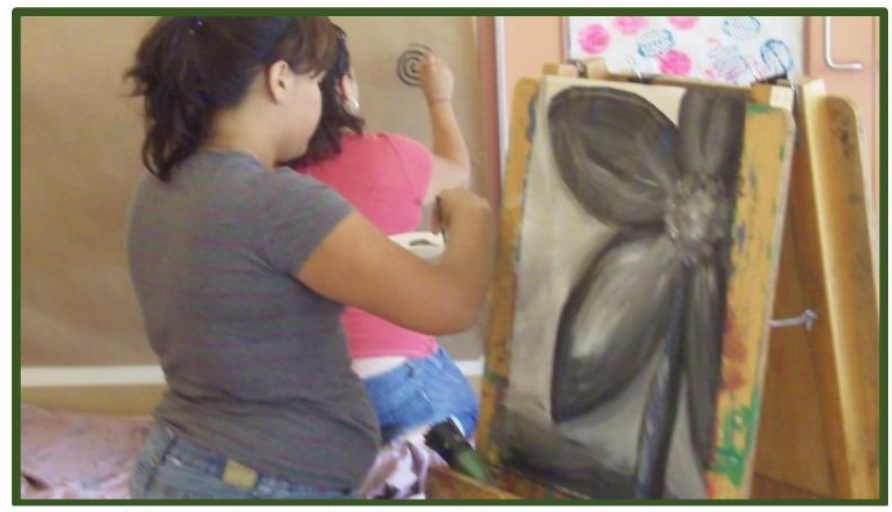

Figure 3. Step by Step Educators during start-up week

\section{Materials, Relationships and the Language of Art}

Since the actual construction of the studios was not complete at the beginning of the school year, mini-ateliers were arranged in the classrooms so teachers could initiate the mindset of Entewate'nikonri:sake (See Fig.4). During those first months, the objective was for teachers and children to build a 'language of art' through open-ended explorations of a variety of art materials and media. We hoped that we all would get to know the art resources better by working collectively, and that our documentation of the interactions between the child and the teacher would support planning for future stages to extend children's learning. This pedagogy aimed to foster methods of interaction, conversation and the shared construction of knowledge between 
teacher and child that responded to children's immediate interests and ideas (Gandini, 2008). The teachers' encounters with children would provide opportunities for a rich 'arts' foundation for cultural projects to follow.

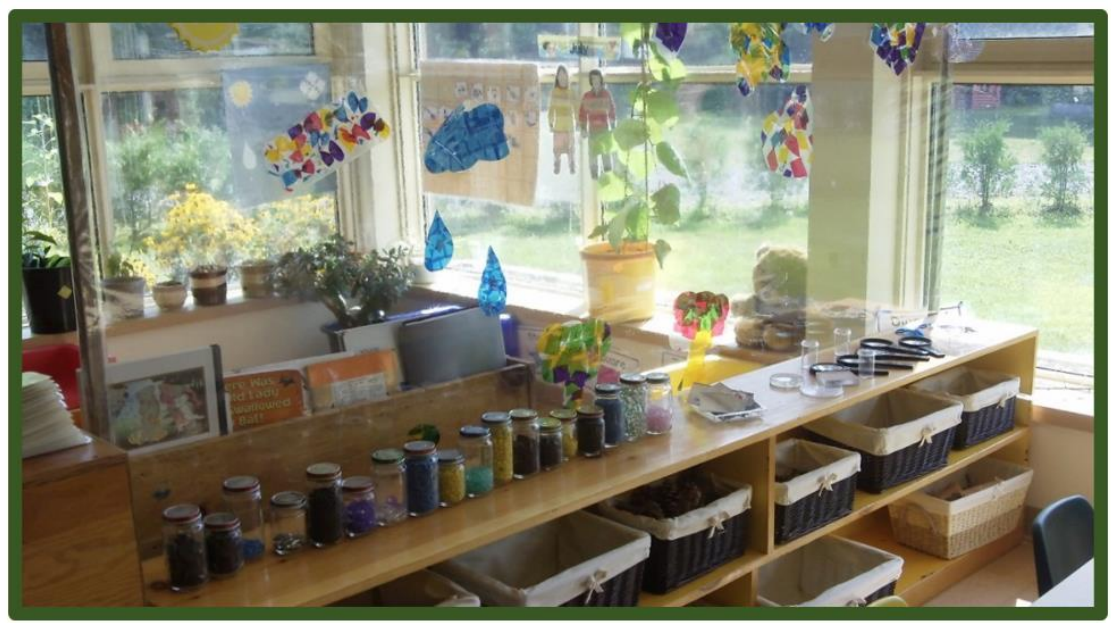

Figure 4: Mini-ateliers in the classrooms

\section{Clay and Children Meet: The Cycle at Work}

The first exploration of clay as a medium extended over months, and was then re-visited again later in the school year during project explorations. We worked extensively to "understand [clay's] identity" (Pelo, 2007, p. 59). Beginning our arts exploration with clay also reflected Indigenous knowledge recognizing clay as "a material fundamental to the human species" (Clemens, 1991, p. 23); a natural by-product of Mother Earth. Mohawk values "are rooted in their acceptance of being caretakers of Mother Earth" (Porter, 2008, p. 28). At Step by Step, giving gratitude for Mother Earth's gifts is discussed daily, beginning in the morning with children's recitation of the Ohén:ton Karihwatéhkwen, a thanksgiving address. This integration of Mohawk culture (through an art medium) with daily activities at the school demonstrated the objective at the heart of this study: to embed culture in experience.

After several weeks of clay workshops the students, teachers and I developed our technical vocabulary (e.g. rolling, pinching, pushing, stacking, pressing); a language of artistic experience that united us. Some classes posted words, in Mohawk, with accompanying photos of the children engaged in their art and new vocabulary. Independently, children would often revisit their experiences and verbalize this developing language. Most of the teachers became better at "holding back" on asking product-driven questions like "What are you going to make?" and took part more in 'discovery' during these sessions.

The children immersed themselves in sensory explorations as they researched impacts on clay. They used tools such as plastic knives, authentic clay carving tools, chopsticks and natural items such as twigs, feathers, pine cones and stones. With every encounter, the children's relationship with the material deepened. This focused art practice provided the children with confidence to develop a language of art with other concentrations (i.e. line, texture, shape and paint), as we moved through our Cycle of Inquiry.

\section{An Arts-based Cultural Project: "Our Culture, Our Ways"}

Our Cycle of Inquiry demanded reciprocal listening between myself, the teachers and the children. Our ability to move through the Cycle depended on being sensitive to what was 
meaningful and enjoyable for all participants. Mohawk culture also reflects a belief in cycles, an acknowledgement in the interconnectedness of everything, and this value is embedded in their relationships (Porter, 2008). This demonstrates another way that we integrated Indigenous knowledge with our learning and educational practice.

Interconnectedness is reflected in the Mohawk's spiritual attachment to the land, their history, community, the story of creation and how they address social problems (Porter, 2008). Early in the school year, we established that a cumulative Cultural Museum would be created, focusing on the theme of relationships. The exhibit was to be called "Our Culture, Our Ways," and from February until the end of May 2011, the projects became the curriculum. After months of developing skills with art mediums and a language for art, teachers introduced the topic of "relationships" to students. The project topics for classes focused on the following:

\begin{tabular}{|c|c|c|c|}
\hline Class & Age Group & Topic & Arts Focus \\
\hline Deidra's class & 18 mos.- 2 yrs. Old & $\begin{array}{l}\text { Our Relationship to } \\
\text { Bugs (insects) }\end{array}$ & $\begin{array}{l}\text { Drawing (line), } \\
\text { painting, clay }\end{array}$ \\
\hline Stephanie's class & 2 year olds & $\begin{array}{l}\text { Our Relationship to } \\
\text { Water. }\end{array}$ & $\begin{array}{lc}\text { Music, } & \text { dance, } \\
\text { drawing } & \text { (line), } \\
\text { painting, drama }\end{array}$ \\
\hline Melissa's class & 2 year olds & $\begin{array}{l}\text { Our Relationship to } \\
\text { the Turtle }\end{array}$ & $\begin{array}{l}\text { clay, drawing (line), } \\
\text { painting }\end{array}$ \\
\hline Glorianne's class & 3 year olds & $\begin{array}{l}\text { Our Relationship to } \\
\text { Festivals }\end{array}$ & $\begin{array}{l}\text { painting, drawing } \\
\text { (line), clay }\end{array}$ \\
\hline Sonia's class & 3 year olds & $\begin{array}{l}\text { Our Relationship to } \\
\text { the Three Sisters } \\
\text { (corn, beans, squash) }\end{array}$ & $\begin{array}{l}\text { Sketching } \\
\text { drawing (line) , } \\
\text { painting, } \\
\text { sculpting(clay) }\end{array}$ \\
\hline Kariiostha's class & $\begin{array}{l}\text { Mixed-age Mohawk } \\
\text { immersion): }\end{array}$ & $\begin{array}{l}\text { Our Relationship } \\
\text { with the Natural } \\
\text { World } \\
\text { (exploring colours of } \\
\text { Mother Earth ) }\end{array}$ & $\begin{array}{l}\text { Painting, drawing } \\
\text { (line) }\end{array}$ \\
\hline Roseanne's class & 4 year olds & $\begin{array}{l}\text { Our Relationships } \\
\text { with Celebrating } \\
\text { Festivals } \\
\text { (music \& clothes) }\end{array}$ & $\begin{array}{l}\text { Music, dance, clay, } \\
\text { sketching and } \\
\text { drawing(line) }\end{array}$ \\
\hline Monique's class & 4 year olds & $\begin{array}{l}\text { Our Relationships } \\
\text { with Kanien'kehá:ka } \\
\text { Long Ago } \\
\text { (storytelling/ the } \\
\text { Longhouse, history) }\end{array}$ & $\begin{array}{l}\begin{array}{l}\text { Sketching, drawing } \\
\text { (line), } \\
\text { sculpting, weaving, } \\
\text { drama }\end{array}\end{array}$ \\
\hline Rebecca's class & 4 year olds & $\begin{array}{l}\text { Our Relationships } \\
\text { with our Community } \\
\text { (Kahnawake) }\end{array}$ & $\begin{array}{l}\text { Sketching, } \\
\text { drawing(line), } \\
\text { sculpting, painting, } \\
\text { drama }\end{array}$ \\
\hline
\end{tabular}




\begin{tabular}{|l|l|l|l|}
\hline Carina's class & 4 year olds & $\begin{array}{l}\text { Our Relationship to } \\
\text { the Forest and the } \\
\text { Animals (clans) }\end{array}$ & $\begin{array}{l}\text { Sketching, } \\
\text { drawing(line), } \\
\text { painting, clay }\end{array}$ \\
\hline
\end{tabular}

\section{Cultural Projects Phase 2}

Our Cycle of Inquiry placed children's investigations at the core of the projects situating teachers as partners in work. Teachers observed the children and listened carefully, recording and photographing them. This documentation later informed their planning as they expanded and facilitated children's explorations. For children, turning to the arts offered creative opportunities to make their thinking visible. Arts methodologies also encouraged the children to deepen their cultural understandings, as demonstrated in this example from one of the projects, "Celebrating Festivals":

As a follow-up to creating actual festival shawls, the girls in the class also created minishawls made out of cardboard. Our revisiting continued mindfulness to who "we" are as a people. The girls were presented with print-outs of Iroquois patterns often found on traditional clothing. They tried the Celestial Dome pattern first. On a practice paper they attempted to reproduce the patterned lines several times. (Comments from the children: "Here are some swirly lines.' "This straight line runs across the bottom and there are hill lines on the top." "This one has bows for lines.") .... After drawing on several duplicated patterns, K. (child) decided she would create some of her own line decorations: heart patterns, butterflies too! I. (child) brought in the natural world with line drawings of trees, turtles and snakes. L. E. (child) was happy to copy the Celestial Dome design. ... she even tried her shawl on one of the classroom stuffed bears! (See Fig.5) (Field note, Roseanne's class, May 20, 2011)
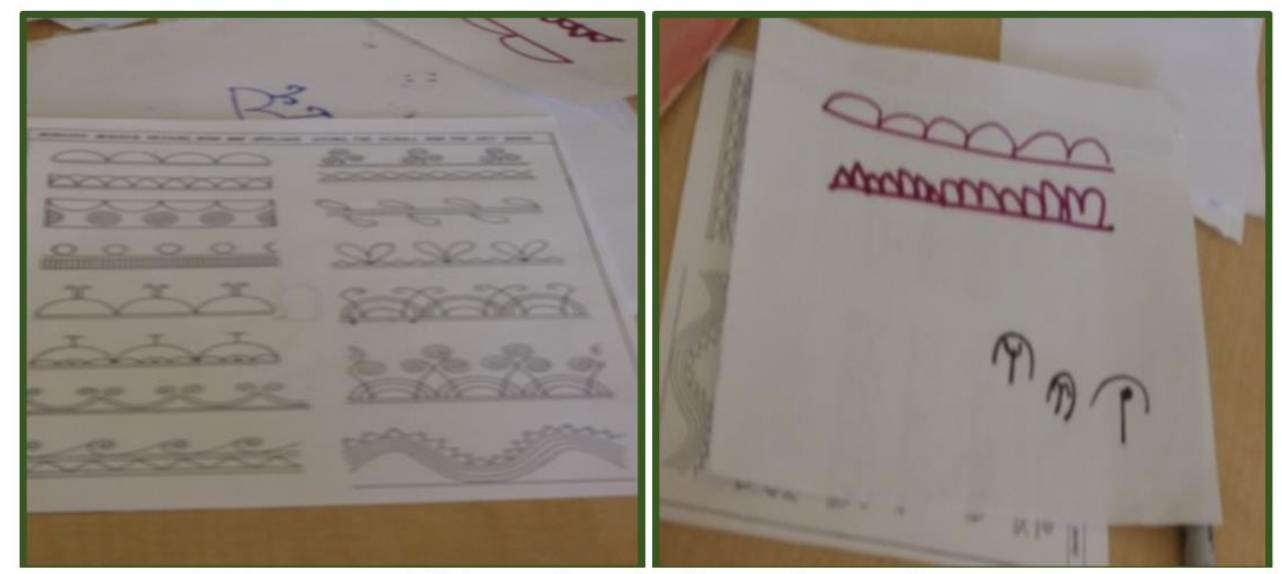

Figure 5. Child practices the lines of Iroquois patterns

I soon realized that Native art customs and symbols were often being incorporated into project work (i.e. weaving, beading, pottery work) (See Fig. 6a \& 6b). In these cases the teachers had to take on the role of teacher with me to explain some of the Mohawk representations and art traditions. While this reminded me of my position as an 'outsider' to the cultural community, it also clarified how educators were integrating culture into curriculum, and prompted meaningful 
discussions between us about the "languages" of Mohawk culture. This helped me to see how arts methodology could expand the teachers', students' and an art audience's cultural experiences.

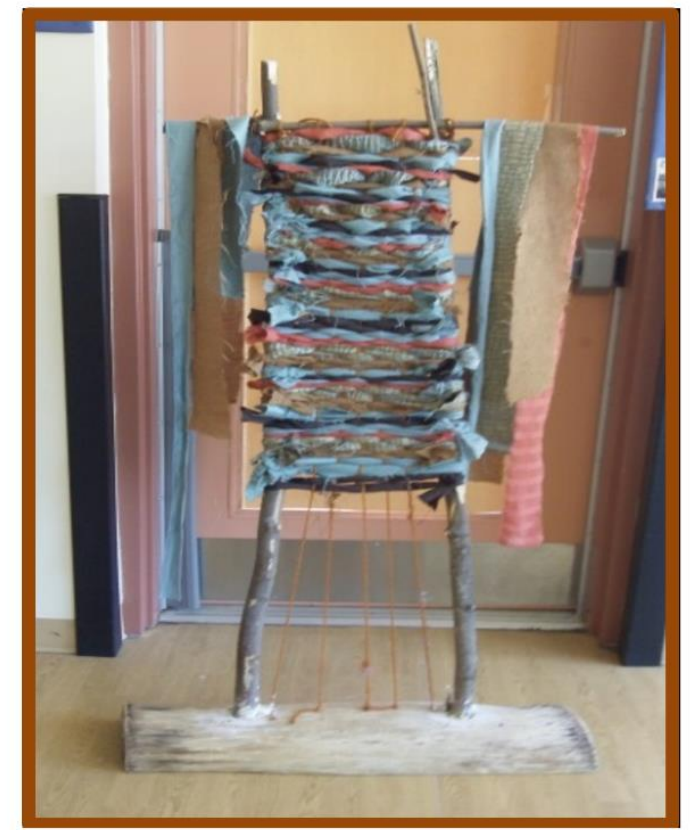

Figure 6a. Weaving from the project: Our Relationships with Kanien’kehá:ka Long Ago

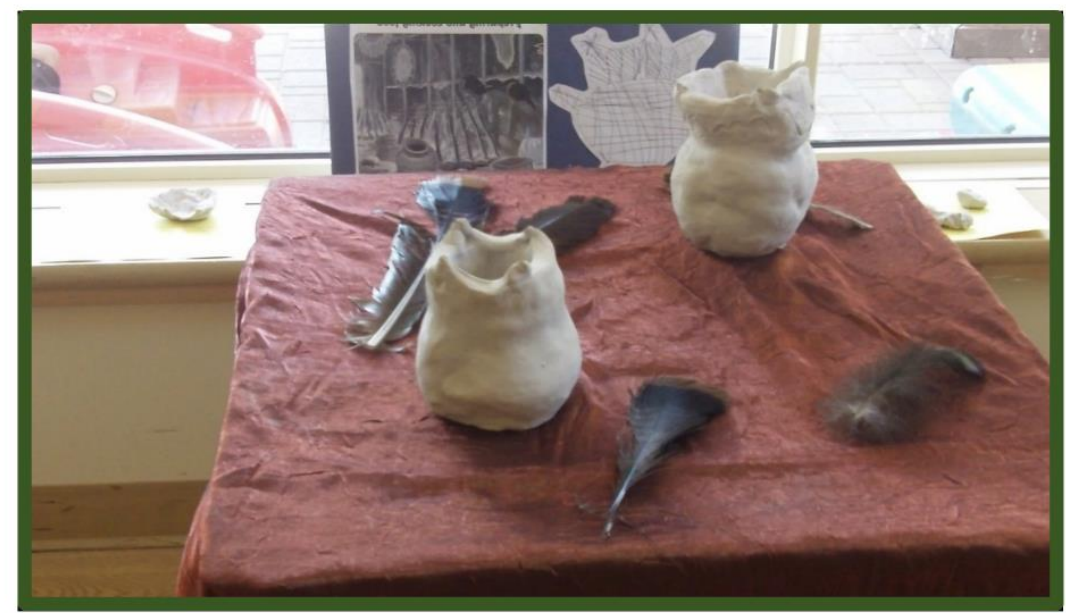

Figure 6b. Pottery (clay) from the project: Our Relationships with Kanien’kehá:ka Long Ago

\section{Discussion of the Research Findings}

Rich, responsive, cultural exchanges in the studios, as evidenced above, helped educators prompt learning and at the same time successfully integrate cultural symbols, values and languages into curriculum. The Step by Step educators' respect for students' autonomy, ability and ways of learning also reflected Indigenous educational approaches, as identified in the following statement: "[We] want education to give [our] children the knowledge to understand and be proud of themselves and the knowledge to understand the world around them" (ICIE, 1972, p. 1). Consistent with Indigenous learning practices, the children first observed, then employed new skills that brought their understandings into active experiences (Rogoff, 2003). The study data 
demonstrated how teachers' offerings of various mediums (i.e. clay, paint, pastels, collage) to foster the language of art, combined with educators' constructivist approach to teaching and learning, fulfilled goals of "...creating the learning environments suited to the habits and interests of the Indian child" (National Indian Brotherhood, 1972, p.18).

Furthermore, the data suggested that the studios improved teacher practice and recognized the significance of educators' voices. As an outsider to the culture, I wanted to attend to their words to accurately represent their experiences (Porsanger, 2004). I studied conversations from my field notes, interviews and journals to examine what was changing in their practice. I highlighted frequent comments that represented the teachers' self-reflections about the integration of the arts (Bogdan \& Biklen, 2006) during their time in the studios: "I learned," "I began to see," "It made me realize," "I now understand" and "I started to be better at...". These terms came from the teachers themselves and demonstrated their intentions to support children's development spiritually, emotionally, intellectually and physically. The educator's reflections illustrate how their changing practice in the studios, and their emphasis on the arts as a tool for meaning-making, impacted and augmented their teaching.

In this research the studios also emerged as critical spaces for encouraging cultural understanding, and illustrated how the educational environment becomes the "third teacher." By recognizing how the studio environments informed learning, educators were able to situate Mohawk culture at the core of their curriculum, and used arts mediums and spaces to develop knowledge and create dialogue, relationships and a deeper awareness of possibilities (Greene, 2004).

Another significant finding concerned the use of Reggio Emilia principles in an Indigenous educational context. Though the Step by Step educators appreciated the tenets of Reggio, "culture" became the most important principle in their classrooms. Both the teachers and I had to "let go" of some Reggio principles to recognize what resonated with the children's own experiences within Mohawk culture and community. Indigenous communities advocate for culturally appropriate systems and educational programs that focus on the needs and values of their communities (Wright, 2003). A key Reggio Emilia tenet, that of the "positive image of the child," was most important for the Step by Step educators and was, perhaps, what attracted them to the Reggio approach in the first place. However, Mohawk ways of thinking, reflected by the educators' commitment to "the cultural survival of their people through the education of their children" (Cajete, 1994; Graveline, 1998; Hampton, 1995; as cited in Wright, 2003) deepened that principle. In their reflections, the teachers identified that the way in which learning happened could not be separated from their culture and customs. This was an important revelation that illustrates that First Nations education must be driven by the First Nations communities.

\section{Ways Forward: Implications for Teaching and Learning in Cultural Curriculum}

To address a rapid increase in the global movement and migration of various cultural communities, schools and teachers need more support to provide effective education for students (Keat, Strickland \& Marinak, 2009). Also, policymakers and teachers must acknowledge the ways that traditional, Western ways of teaching and learning can fail students from other cultures. Many teachers do not have the knowledge of how various cultures learn and develop (Keat et al., 2009), nor have they been given instruction in alternative education approaches that include culture. I hope that this study encourages more research and innovation in early childhood classrooms that integrates culture with curriculum design and practice, and have seen how the arts can help teachers reach this objective. 
This study can also provide guidance for Indigenous communities engaged in developing their early childhood care. The phases of research here affirm that reform, or growth of any program, cannot be focused solely on curriculum. Pedagogical development in communities needs to encompass all stakeholders as well as being responsive to the fact that each community may hold unique values, beliefs and traditions. Ball and Pence (2000), Battiste (2002), and many others emphasize that there are differences amongst First Nations communities; therefore the future of their education relies on the participation of all members of the communities (i.e. parents, teachers, leaders, grandparents, children, foster parents, elders). Again, groups can consider the arts as an agent for promoting cultural identity.

This research provides insight into various critical considerations educators must contemplate when they integrate culture into early education models. My hope is that this work will inspire and support further inquiry into culture and learning through the arts, and the recognition of the environment as third teacher in Indigenous and many other "cultural classrooms".

\section{Acknowledgements}

This research was supported in part by a grant from The Fonds de Recherche du Québec Société et Culture.

\section{References}

Arsenault, N. \& Anderson, G. (1998). Qualitative research. In Fundamentals of educational research (p.119-135). Bristol, PA: Falmer Press, Taylor \& Francis.

Ball, J. \& Pence, A. (2000). A post-modernist approach to culturally grounded training in early childhood care and development. Australian Journal of Early Childhood. 25(1), 21-25.

Battiste, M. (2002). Indigenous knowledge and pedagogy in First Nations education: A literature review with recommendations. Retrieved from

http://www.afn.ca/uploads/files/education/24._2002_oct_marie_battiste_indigenousknowledgean dpedagogy_lit_review_for_min_working_group.pdf

Bogdan, R.C., \& Biklin, S.K. (2003). Qualitative research for education: An introduction to theories and methods. ( $4^{\text {th }}$ ed.) Boston: Allyn \& Bacon.

Butler-Kisber, L. (2010). Qualitative inquiry: Thematic, narrative and arts informed perspectives. Thousand Oaks, CA: Sage.

Clavir, M. (2002). Preserving what is valued: Museums, conservation and First Nations. (p. 7375).Vancouver, B.C.: UBC Press.

Clemens, S.G. (1991). Art in the classroom: Making every day special. Young Children 5(46), 13-19.

Davis, Y. N. (2006). Belonging and the politics of belonging. Patterns of Prejudice, 40(3), $197-$ 284. 
Derman-Sparks, L. \& Olsen-Edwards, J. (2010). Anti-bias education for young children and ourselves. Washington, DC: NAEYC.

Fraser, S. (2006). Authentic childhood: Experiencing Reggio Emilia in the classroom. Toronto, Ontario: Thomson Nelson.

Fraser, S. (2007). Play in other languages. Theory into Practice, 46(1), 14-22.

Gandini, L. (1998). Educational and caring spaces. In C. Edwards, L. Gandini, \& G. Forman, (Eds.) The hundred languages of children: The Reggio Emilia approach to early childhood education - Advanced Reflections. (pp. 161-178). Norwood, NJ: Ablex.

Gandini, L. (2008). Introduction. In L. Gandini, S. Etheridge, \& L. Hill (Eds.) Insights and inspirations from Reggio Emilia: Stories of teachers and children from North America. (pp. 136). Worcester, MA: Davis Press.

Gandini, L., Hill, L., Cadwell, L., \& Schwall, C. (Eds.) (2005). In the spirit of the studio: Learning from the atelier of Reggio Emilia. NY and London: Teachers College Press.

Greene, M. (2004). Carpe diem: The arts and school structuring. In G. Diaz \& M. B. McKenna (Eds.), Teaching for aesthetic experience: The art of learning (pp. 17-31). New York: Peter Lang.

Hughes, E. (2007). Linking past to present to create an image of the child. Theory into Practice, 46 (1), 48-56

ICIE (1972). Indian control of Indian education. Policy Paper National Indian Brotherhood/Assembly of First Nations. Retrieved from: http://www.aincinac.gc.ca/ai/rqpi/apo/index-eng.asp

Joint First Nations/Inuit/Federal Child Care Working Group (1995). Considerations and recommendations for the First Nations/Inuit child care program and funding framework. Ottawa: The Group.

Kantrowitz, B., \& Wingert, P. (1991, December 2). The ten best schools in the world. Newsweek, 118 (23), 50.

Katz, L. (2010). How young children learn: Part 1. In S. Schmidt (Ed.), Key issues in early years education: A reader (pp.9-14). New York: Routledge.

Keat, B., Strickland, M.J., \& Marinak, B.A. (2009). Child voice: How immigrant children enlightened their teachers with a camera. Early Childhood Education (37), 13-21.

Kirkness, V. (1999). Aboriginal education in Canada: A Retrospective and a prospective. Journal of American Indian Education, 39, (1). 
Knudson, E.I., Heckman, J.J., Cameron, J.L., \& Shonkoff, J.P. (2006). Economic, neurobiological and behavioural perspectives on building America's future workforce. Proceedings of the National Academy of Sciences, 103, (27).

Maykut, P., \& Morehouse, R. (1994). Beginning qualitative research: A philosophical and practical guide. (pp. 9-45). Bristol, PA: Falmer Press.

National Indian Brotherhood (1972). Indian control of Indian education: Policy paper. Ottawa, ON: Author. Retrieved from http://64.26.129.156/calltoaction/Documents/ICOIE.pdf

New, R.S. (2007). Reggio Emilia as cultural activity: Theory to practice. Theory into Practice (46)1, 5-13.

Novick, R. (1996). Developmentally appropriate and culturally responsive education: Theory and practice. Portland, OR: Northwest Regional Educational Laboratory. (ERIC ED 397 985).

Pelo, A. (2007). The language of art: Inquiry-based studio practices in early childhood settings. St.Paul, MN: Redleaf Press.

Penn, H. (2010). How young children learn. In S. Smidt (Ed.), Key issues in early years Education: A reader. (2 $2^{\text {nd }}$ ed.)(pp.18-23). New York: Routledge.

Piaget, J. (1966). The construction of reality in the child (pp.30-75). NY: Ballantyne Books.

Porsanger, J. (2004). An essay about Indigenous methodology. Nordit: Special issue on northern Minorities, 105-120. Retrieved [on line]: http://septentrio.uit.no/index.php/nordlit/article/view/1910

Porter, T. (2008). And Grandma said...Iroquois teachings as passed down through oral tradition. Bloomington, IN: Xlibris Corporation.

Rinaldi, C. (1998). Projected curriculum and documentation. In C. Edwards, L. Gandini \& G. Forman (Eds.), The hundred languages of children: The Reggio Emilia approachAdvanced reflections (pp. 113-125). Norwich, CT: Ablex.

Rinaldi, C. (2006). In dialogue with Reggio Emilia: Listening, researching and learning. New York: Routledge.

Robinson, K. \& Jones Diaz, C. (2006). Diversity and difference in early childhood education: Issues of theory and practice. Colombus, Ohio: Open University Press.

Rogoff, B. (2003). The cultural nature of human development. New York: Oxford University Press.

Snyder, S. (2001). Connection, correlation and integration. Music Educators Journal, 87(5), 
$32-39$.

Vecchi, V. (2010). Art and creativity in Reggio Emilia: Exploring the role and potential of ateliers in early childhood education. NY: Routledge.

Vygotsky, L.S. (1978). Mind in society: The development of the psychological process. Cambridge, Mass: University Press.

Wright, S. (2003). The arts: Young children and learning. Boston, MA: Pearson.

Endnotes

${ }^{\mathrm{i}}$ The studio (or atelier) environment allows individual or small groups of children to explore arts-based approaches to a topic. It represents a space where relationships (i.e. child and peers; child and teacher; child and materials) can unfold. The meaning of the Mohawk word is: a place where we will gather and great thoughts will come together.

ii The Reggio Emilia approach considers a child's parents as the first educators; the teacher as the second educator and the learning environment as the third. The classroom as a space encourages children's active encounters, communication and the development of relationships. Teachers work to enhance this environment by adding materials, artifacts and documentation that revisit children's experiences. 